\title{
Results and Advantages of a Spatially-Variable Technology for Crop Yield
}

Kent A. Klemme, Joseph A. Schumacher, and Donell P. Froehlich

South Dakota State Univ.

\section{DISCLAIMER}

This report was prepared as an account of work sponsored by an agency of the United States Government. Neither the United States Government nor any agency thereof, nor any of their employees, makes any warranty, express or implied, or assumes any legal liability or responsibility for the accuracy, completeness, or usefulness of any information, apparatus, product, or process disclosed, or represents that its use would not infringe privately owned rights. Reference herein to any specific commercial product, process, or service by trade name, trademark, manufacturer, or otherwise does not necessarily constitute or imply its endorsement, recommendation, or favoring by the United States Government or any agency thereof. The views and opinions of authors expressed herein do not necessarily state or reflect those of the United States Government or any agency thereof. 


\title{
Results and Advantages of a Spatially-Variable Technology for Crop Yield
}

\author{
Kent A. Klemme, Joseph A. Schumacher, and Donell P. Froehlich
} South Dakota State Univ.

\begin{abstract}
The Ficld Grid Sense system was adapted to locate and record crop yicld in the field. Accurate measurement of yicld in spatially variable ficlds is needed to achieve maximum profitability in crop production. The harvester system is composed of a laptop computer, data acquisition system, fifth whecl, and an ultrasonic level sensor asscmbled on a combinc. The fifth whed, in combination with travel lanes, is used to identily yicld with position where yicld is determined by the change of grain volume in the combire hopper. Yicld maps can be generated from the collected data and then used as a production management tool in conjunction with other ficld characteristic information.
\end{abstract}

\section{INTRODUCTION}

PURPOSE - Accurate measurements of yicld and other ficld characteristics are needed to achicve maximum profitability in crop production. The Ficld Grid Sense (FGS) systcm provides a means of yicld mapping. Locating yicld variations in the ficld and making comparisons to soil maps and fertilizer application rates can be advantageous for determining possible production problems.

1. Numbers in parenthesis refer to the references listed at the end of the manuscript.

The use of equipment and/or products in this study is not intended to endorse or discredit the manufacturer or product by the rescarchcts, SDSU, andor SAE. QLANE ${ }^{\text {Me }}$ software is copyrighted and FGS is patent pending.
Crop production efficiency can be increased by knowing the site specific yield and grain moisture contents. Over scveral years a data base can be compiled with FGS and prescription farming can be used to increase profitability. Expensive fertilizers and herbicides can be applied at varying rates based on yicld and other sitc specific data to insure that these products are used as cfficiently as possibic.

The FGS harvester system could also be used to eliminate discrepanciesbetween landlords and tenants over sharecrop amounts. The system is also functional for test plot yicld detcrminations and showing the yicld fluctuation across the plot. Bencfits of accurate yicld maps displaying the yield variations due to spatial variability of the ficld are noticcable both economically and environmentally.

The benefits of yicld mapping are noticcable 'rom past research done be several partics and their varying yield determination methods. A grain flow sensor was developed using piczo-film (1)'. The film was mounted under the combine sicves to correlate an impact rate to a harvesting grain flow. This flow was then converted to a yicld for the development of yicld maps. Ficld tests and laboratory tests were performed. For better accuracy a larger area of the sicve needed to be covered with the impact sensor.

Yicld was mapped according to grain flow determined by a Claydon Yicld-o-Mcter manufactured by Shelbourne Reynolds Enginecring in England. The flowmeter mounted on the discharge side of the grain bin auger, consisted of a paddle wheel and grain llow was sensed as a function of the rotation of the paddle whecl. The researchers concluded that the system showed the yicld variability across the ficld with reasonable accuracy. Ilowever, in low grain yicld $r$ enas the yicld was overestimated by the system due to smoothing of the data (2).

In another method, the amperage was measured to a motor which drove the clean grain auger to delermine the 
grain flow into a combine (3). The greatest crror in grain Now measurements in an auger was due to variations in the grain moisture content (4). The change in momentum occurring from a direction change of the grain was used as an indication of grain now. $\wedge$ force derived from the combination of friction and impact caused by the flowing grain could be filtered so that yields could be mapped (5). $A$ capacitance grain flowmeter and a nucleonic grain nowmeter were also rescarched (6).

The combine causes many problems in determining grain flow throughout the machinc. The time interval as the grain flows from the head to the flow sensor is called the transportation delay. The redistribution of grain within the combine is represented by a time constant. Combining these terms results in a model using a first order time delay (2).

Locating position for a particular grain yicld within the field can be done in several ways. Some of these methods include dend reckoning, radio wave triangulation, and glohal positioning. Construction of tralfic lanes takes some initial preparation (7). However, it is a low investment, and does perform satisfactory. Radio location, such as triangulation, can be used in many cropping practices (2). An emerging technology, Global Positioning Systems, (GPS), is fast becoming an alternative to other techniques of positioning. With decreasing costs and improving accuracies, it may soon replace other methods (8).

BENEFITS - Grain yicld mapping systems are restricted by many factors present in the field or on the combine. Some of these factors include the space available on the machine, physical variables of the grain, machine vibration and electrical noise, topography, and environmental conditions. The system we selected to gencrate instantancous yield maps minimizes the unwanted effects from the factors mentioned above. The FGS combine system provides maps of both the grair yield and grain moisture content at a specific point in the field. The system also generates topography maps of the ficld. The system includes temperature and grain moisture affects in determining the yicld. This insures that all compensations are performed before the yicld map is generated and the consumer can gather the needed information directly from the map. The information collected can then be used for locating last season's crop production mistakes and fine tuning next season's crop inputs.

Correct chemical applications based on yield and soil characteristics can be beneficial to everyone. The producer saves moncy by applying variable rates which correspond to the needs of the crop and the soil. This ensures that the products applied were correctly prescribed and used, therefore leaving no chemicals present to contaminate other parts of the environment. Agricultural practices can contaminate the surface waters and groundwater, and a top priority of prescription farming is to minimize agriculture's effects on the environment (9). An accurate measure of yicld specific to the location in the field is mandatory for this method of farming. Salfe use and correct methods of farming can decrease the chances of damage to all the resources present within the environment.

OBJECTIVES - The information collected could improve crop production efficiencies ohtained by fine tuning crop production techniques to fit the environment, equipment, and the producer. objectives:

Therefore, research was initiated with the following

1. Adapt QI.ANI: soflware and the I:GS mapping and control system for use with the combine so that it performs instantaneous yield mapping, grain moisture mapping, and topography mapping controlled by a laptop computer.

2. Evaluate the described FGS combine system based on performance of the components.

\section{MATERIALS AND METIIODS}

The FGS harvester system was designed to document the locition of crop performance in the ficld. This performance is hased upon moisture corrected grain yield. The yicld mapping system consists of eight parts: distance sensor, laptop computer, data logger, control box, a file containing the field map, ultrasonic level sensor, and two electronic clinometers. These components were mounted on a TR 86 New Ilolland Combine. The computer collected and recorded all pertinent information from the sensors listed above.

The yicld mapping system used controlled travel lanes established earlier during preplanting operations. Lanes are numbered and can be harvested in any order. Therefore field location is determined by the lane being harvested and the distance traveled down the lane. At the start of a new lane the number of the lane is entered and the initial distance is zero. Grain moisture contert, pitch, roll, yield, and distance are recorded by the dalta acquisition system. 'This information is available for viewing hy the user. The system records the data from the above sensors during field operation from a given field, which is broken up into grids. These grids are approximately 12.2 meters long and the width is equal to the width of the combine head currently being used. This grid size is large enough to notice topography, grain moisture, and yicld changes, and yet small enough to climinate the possibility of missing important fluctuations in one or more of these factors. Afier harvesting a field, a map can be generated. This map will display the changes in yield and grain moisture content throughout the field. The map depicts fuctuations in the factors noted above in grids eyual to or larger than the size described. Therefore the smallest grid would be 12.2 meters by the width of the head, and the largest grid for a particular lane could be the width of the heid by the entire length of the lane.

The time delay corresponding to the time at which the grain is cut until it reictics the yicld sensor wass determined and used as an average of 22.5 seconds. The transportation delay ranges from 20 ) 1025 seconds for this combine (10). More rescarch is necd do that more 
921651

reliatle values can he used to determine this delay based on combine ground speed and the thickness of the crop. It is noticed that the delay is larger when leaving the crop than when entering. This is an important problem that necds to be addressed further if the accuracy of spatial yicld maps is to he improved.

SYSTEM COMPONENT DESCRIPTION - The devcloped instrumentation system controls various components of the system and records the field data necessary to meet the objectives of the research. The instrumentation configuration is shown schematically in Figure 1.

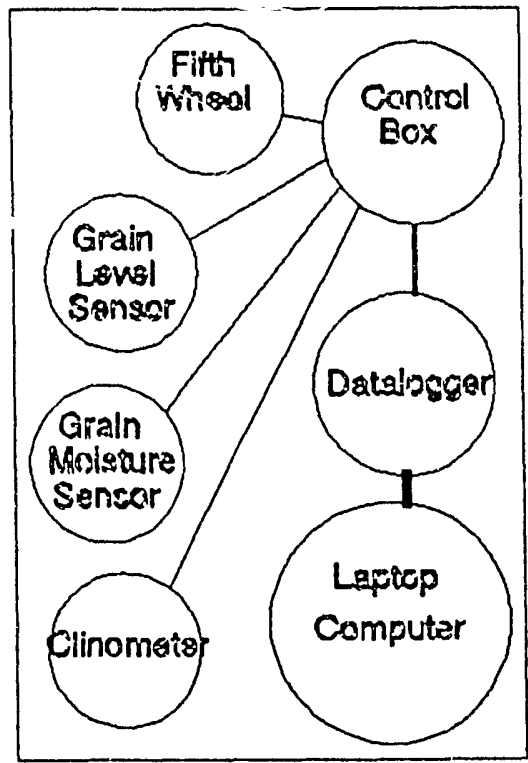

Figure 1. Diagram depicting the main components used to collect the data to develop field maps.

Microcomputer - $A 640 \mathrm{~K}$ IBM compatible Zenith SuperSport laptop computer controls the various components of the system and stores the data collected onto disk. An RS-2.32 scrial port interface was used to link a Camphell Scientific $21 \mathrm{X}$ Micrologger to the laptop computer. Two $31 / 2$ inch disk drives were used by the system. Drive $\wedge$ contained the diskette with the FGS software and combine programs. Drive B stored all pertinent ficld data for a given ficld. This configuration kept the main program safe from possible damage and allowed the user to easily store and retricve records for specific ficlds.

Within the environmentaly controlled climate of the combine cab the laptop computer performs the functions required to operate the system. The laptop is placed on a shelf next to the operator's right shoulder.
This placement permits the freedom of operation of the other controls and still makes the computer availatile for vicwing and keying in functions (Figure 2). The portability of a laptop allows for many uses by the farmer other than just field data acquisition, such as husiness record kecping and forecasting management decisions.

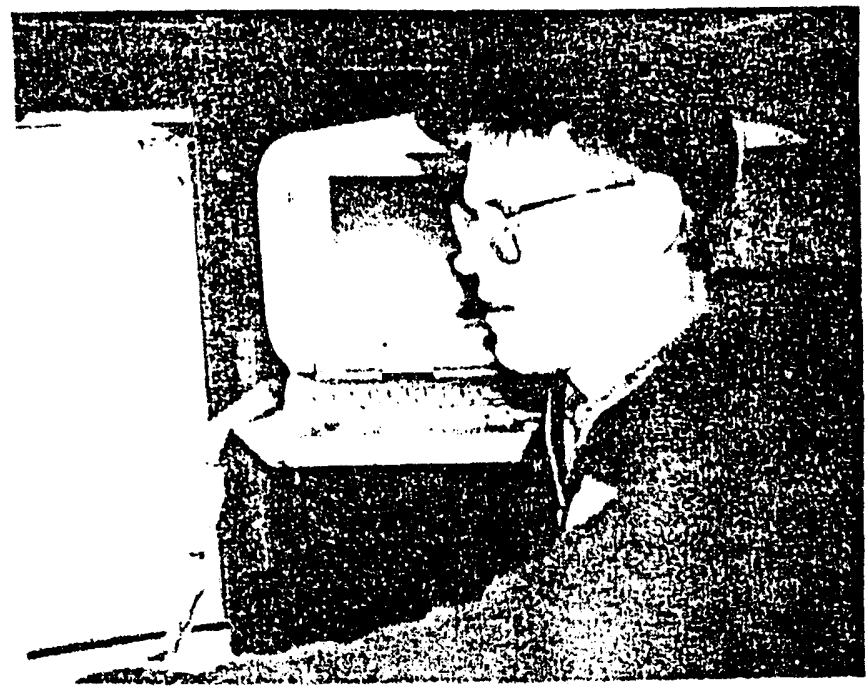

Figure 2. This laptop position in the combine cab provides for viewing and access to other controls.

Dala Acyuisition - $A$ Camphell Scientific 21x Micrologger reccives signals from either the sensors or from the control box. From here the signalis are relayed to the laptop computer. $\wedge$ program was constructed to control the acquisition of the signals from the various sensors. This allows the laptop to use its capahilities for other functions rather than communicating with the sensors and waiting for processing functions to be completed. The micrologger also acts as a data hackup valve by storing the data from the ficld in it's internal memory in raw form. If a diskelte or the lapiop malfunctions the hackup data is still present in the micrologger, if this device is also not turned off

The micrologger is powered through the control box and receives signals from the sensors in the form of voltage differentials or pulse inpuls. The voltage differentials are confined to a $+1-5 v D C$, and the pulse inputs are collected in terms of number of crounts. Position of the data logger is shown in figure 3. 


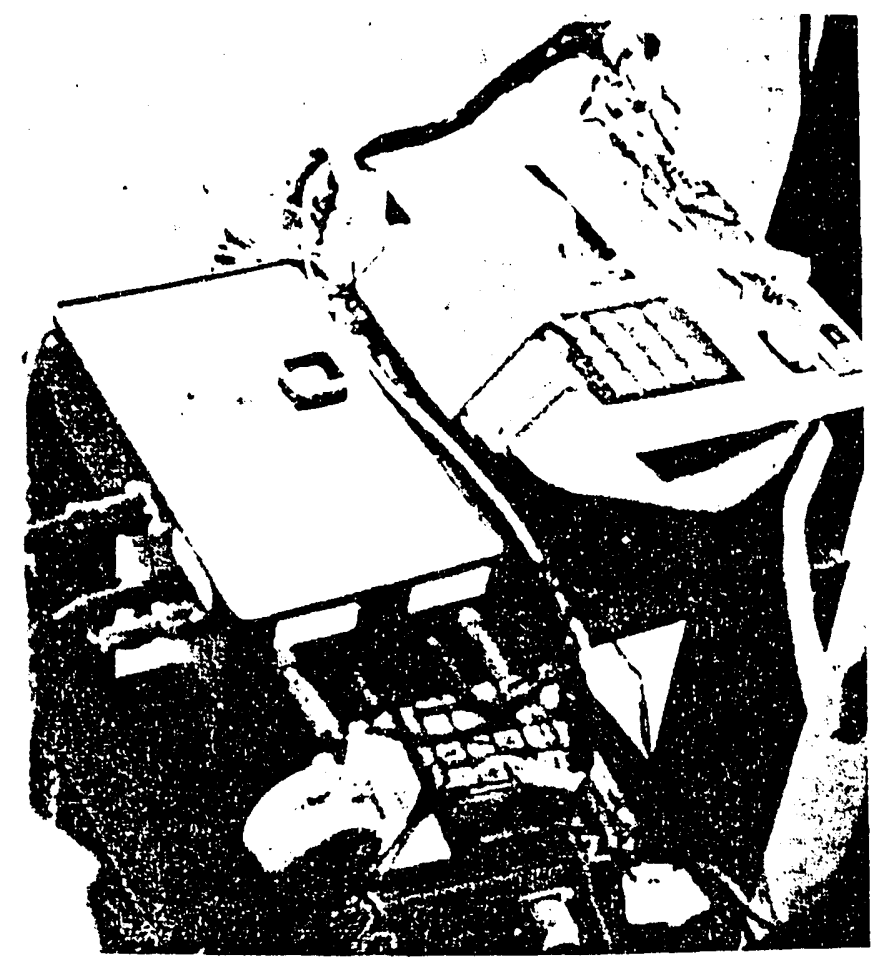

Figure 3. Milltronics MultiRanger Plus Ultrasonic driver box on lower shelf, control hox on left side of top shelf, and data logger on right half of top shelf.

Interface Control Box - $A$ control box was designed and built to contain the electronic circuits needed to convert signals, regulate voltages, power sensors and equipment, and house system control switches (Figure 3 .)

Within the control box the ultrasonic $4-20 \mathrm{~mA}$ signal is converted to a voltage output for the data logger with the use of a quarter bridge. The grain moisture and temperature signals are processed with the use of voltage divider circuits to establish signals within the +/- 5 vDC range tolerable by the data logger.

Power is sent and regulated at 5 VDC to the magnetic pickup and clectronic clinometers with the use of a voltage regulator.

The control trox contains a master power switch which turns on or off the power to all components, except the laptop computer. Also located on the control hox are two loggle switches. "The first toggle is a "hold" switch, when on allows a corresponding voltage which instructs the computer to hold all functions. This is useful when the operator needs to stop the machine for some minor adjustments. The second toggle is a "change lane" switch and is used to inform the computer at the completion of a harvested lane. At this point ditla for the finished lane is saved onto a diskelte and a new lane to be harvested can he selected.
Ultrasonic Level Sensor - An ultrasonic level sensor from Milltronics was used to measure the depth of the grain in the combine hopper (Figure 4). 'This mensurement of depth corresponds to a volume of grain, given that the dimensions of the tank are preciscly known. The change in volume over a given distance traveled by the combine yields a value representing the grain yield present for the area just harvested.

It was assumed that one depth measurement was sufficient in determining the depth of the grain. An optimum placement of the sensor over the grain wass determined in a manner similar to grain depth in a circular grain bin. If the grain is peaked at the eenter of the hin, measuring the depth at one-half the radius would approximately correspond to the depth if the grain wils leveled. Starting with this concept and through testing, this sensor placement was determined for the combine used. Machine vibration and grain moisture content do affect the accuracy of the depth measured. Ilowever, inilial research begaln with the most simple configuration, a one point measurement, and developed from there.

Basic ultrasonic operalions involve the principles of using the time required for a transmilled electronic pulse to he echoed back from a malterial or surfice. Milleronics uses an advanced version of this technolugy by continually storing an updated ultrasound profile in memory. This lechnique, called echo enhancement, increases the degree of reliability of ultrasonics.

The MultiRanger Plus, as used during this research, consists of a driver box containing the electronics and components which control the ultrasonic signal, and removable programmer for specific programming needs. Easy setup and programming allow for fast installation and use of this device. All parameters describing the task for which the device is to be used are entered by keying in codes with the removable programmer. Alterations in the program are quick and results can be viewed al once on the LCI display located on the driver box (Figure 3 ).

Resolution of the ultrasonic system, as provided by the manufacturer is $0.1 \%$ of range, while accuracy is $0.25 \%$ of full range. The device can be operated in temperatures of -20 to 60 degrees Celsius, with temperature correction available if large temperature changes occur during operation. The electronics also contain a MK2 "leurz" Filter to smooth small variations in level from surface waves. An agitator filter can also be used to remove unwanted effects on the signal cilused by the agititors or crossbracing.

The MultiRanger Plus is used to drive the ultrasonic signal, while the $21 \mathrm{x}$ and the laptop computer do the processing necessary to store the dalta in proper format. 


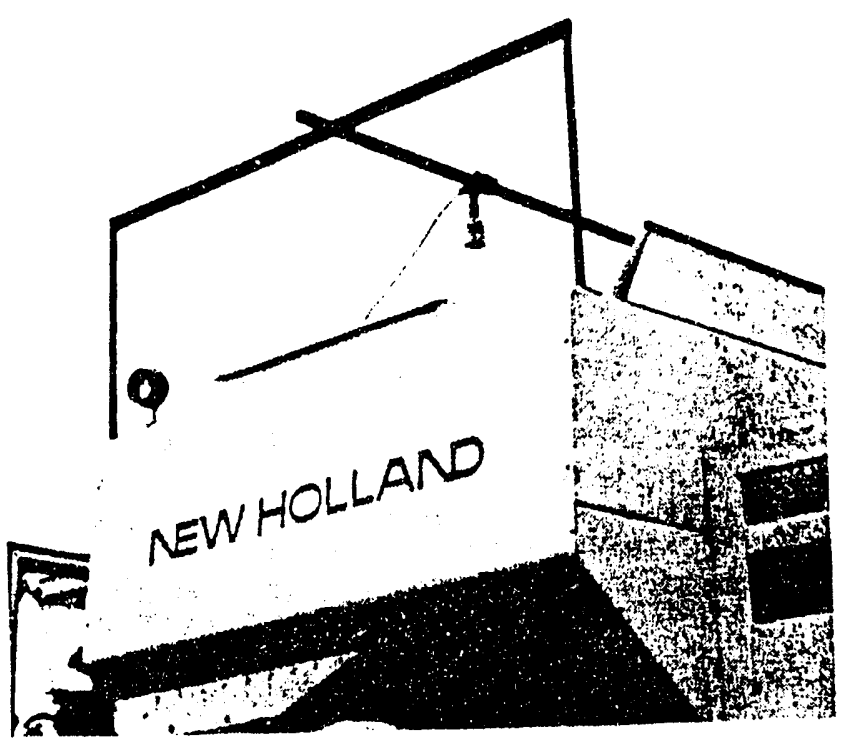

Figure 4. Location of the ultrasonic level sensor over the combine tank for yicld determination purposes.

Grain Moisture and Temneralure Sensor - Grain moisture content is necded to determine the yicld on the go based on number two corn. To account for temperature differences of grain occurring during the harvesting season a temperature transducer is included in the system. Change in temperature affects the actual moisture content of the grain.

The Iransducer selected was built by David Manufacturing Company. This sensor includes a capacitance sensitive moisture sensor fin, and a current sensitive temperature transducer, or monolithic type. Ilowever, the response time of the temperature transducer to notice temperature changes was not what was required by this system, and therefore the data from this part of the apparatus was not included in determining the grain moisture content. A thermocouple might be a better choice for this need, if temperature considerations are necded to determine grain moisture contents precisely.

The sensor, named Calc-U-Dri, consists of a plastic hox containing al stainlessstecl capacitance sensilive fin and a current sensitive temperature transducer. The sensor is mounted in the grain hopper fill auger, therefore most of the grain hows past the sensor, yiclding a representative sampling of the grain for moisture content (Figure 5).

The capacitance fin operates at a frequency of 1 MII\%, which allows almost instantancous reading of the moisture content of the grain passing through the auger. This moisture reading corresponds to the grain that just entered the tank. Therefore, this moisture can be used to determine the corrected yicld. $\Lambda$ calibration curve was

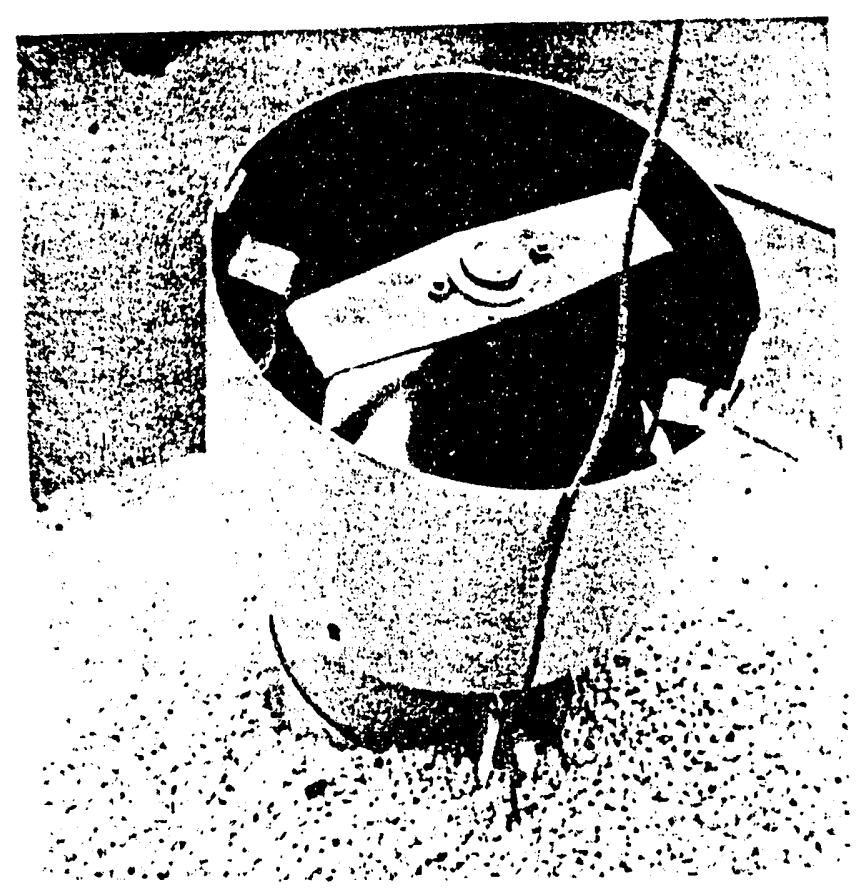

Figure 5. Placement of the grain moisture and temperature sensor on the hopper fill auger.

supplicd by DMC which was uscd as a starting point for programming of the moisture signal.

Fifth Whecl and Position Sensing - To measure the ground specd of the combine and the distance traveled down the lane a fifth whecl was used. This was the same device used for the fertilizer and direct injection spraying FGS projects conducted at SDSU (11).

The fifth wheel consists of a bicycle fork attached to a parallel linkage which mounts to the combinc's framc. The whecl was place direclly behind the path of the left front drive whecl. The drive whecl crushed stalks and other debris allowing the fifth whecl to ride over a conditioned path. To maintain constant contact between the wheel and ground a spring was attached to the fifth whecl configuration (Figure 6). This reduces slippage, excessive vertical motion, or jumping. Six equally spaced blot heads are welded on the rim of the fifth whecl. An Airpax Magnetic pickup, altached to the fork of the apparalus, generates a voliage spike which correspond to a count recorded by the micrologger. Every six counts is one rotation of the whecl. The specd of the counts gencrated yiclds the ground speed and the number of counts indicates the distanced traveled.

Schumacher, found that the median rolling circumference is $1.554 \mathrm{~m}$ (5.097 [i) for this fifth whecl. Extensive tests on varying soil conditions were conducted to determine this result. 


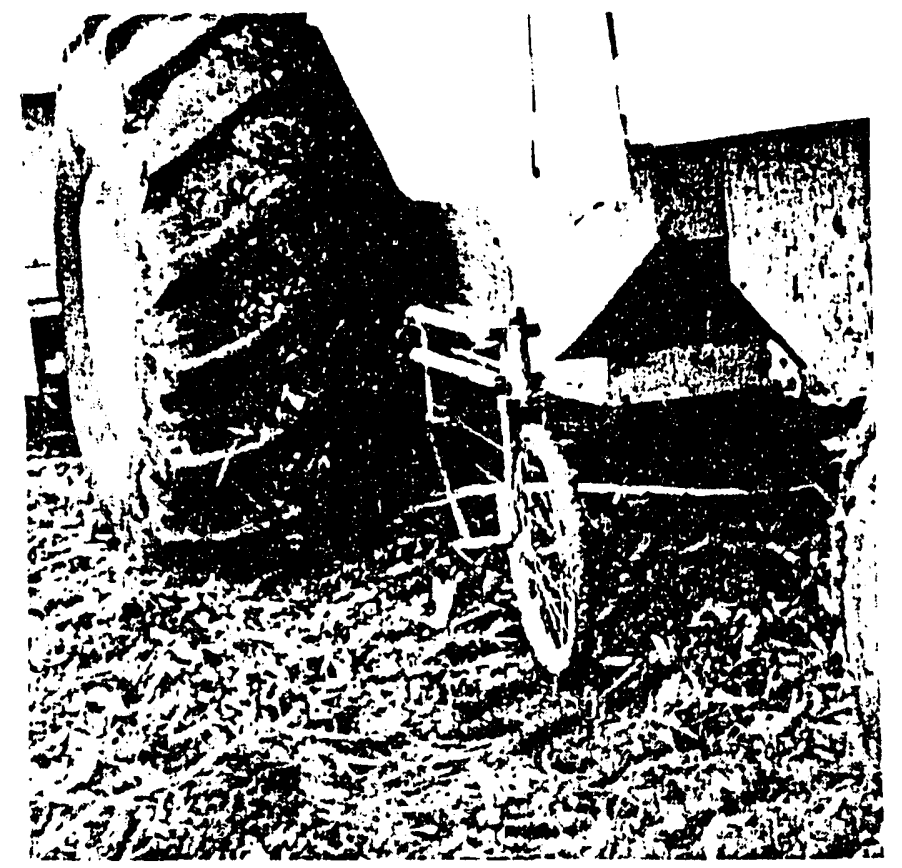

Figure 6. Fifth wheel Configuration with magnetic pickup placed in the path of the combine drive wheel.

Electronic Clinometers - With the use of an AccuStar Electronic Clinometer an accurate angle measurement of the surface of the field can be taken. These measurements are used to crente a topographic map of the field. Two clinometers are mounted on the combine to measure the change of slope in two directions. The pitch and roll of the combine were used to measure these angle changes.

The clinometers consist of a two inch diameter metal casing which houses a capacitor based sensor. A center plate etched to form two linear variable capacitors is placed between to housing halves. The device is half filled with a dielectric liquid and an inert gas. The rotation of the sensor produces a linear output in capacitance and with a conversion a ratiometric voltage output.

The electronic clinometer is a ratiometric device with 5 VDC power required. This produces an output of 2.5 vDC and a $+/-0.016$ volts per degree of rotation. Total range of the device is $+1-60$ degrees, linear range is $+/-45$ degrees, with a resolution of 0.001 degree, and the time constant is 0.3 scconds. Linearity of the device changes with the ranges of the angle. From 0 to 10 degrees linearity is $+1-0.1 \%, 10$ to 45 degrees $+1-1 \%$ of the angle, and from 45 to 60 degrees the signal is monotose. This device's operation range is large enough for field purposes and the resolution is greater than that needed to create topography maps. Operating temperatures are -40 to 6.5 degrees Celsius, and a small adjustment for temperatures out of this range is 0.008 degrees per degree (elsius.

One of the clinometers wals mounted on the rear axle of the combine to measure the roll which indicates the change in slope of the field in the direction perpendicular to travel. The other clinometer was mounted above the front axle to measure the pitch of the combine which corresponds to the change in slope of the licld in its direction parallel to travel (ligure 7). With this data a map depicting the topography of the field can he created and used as a production management tool.

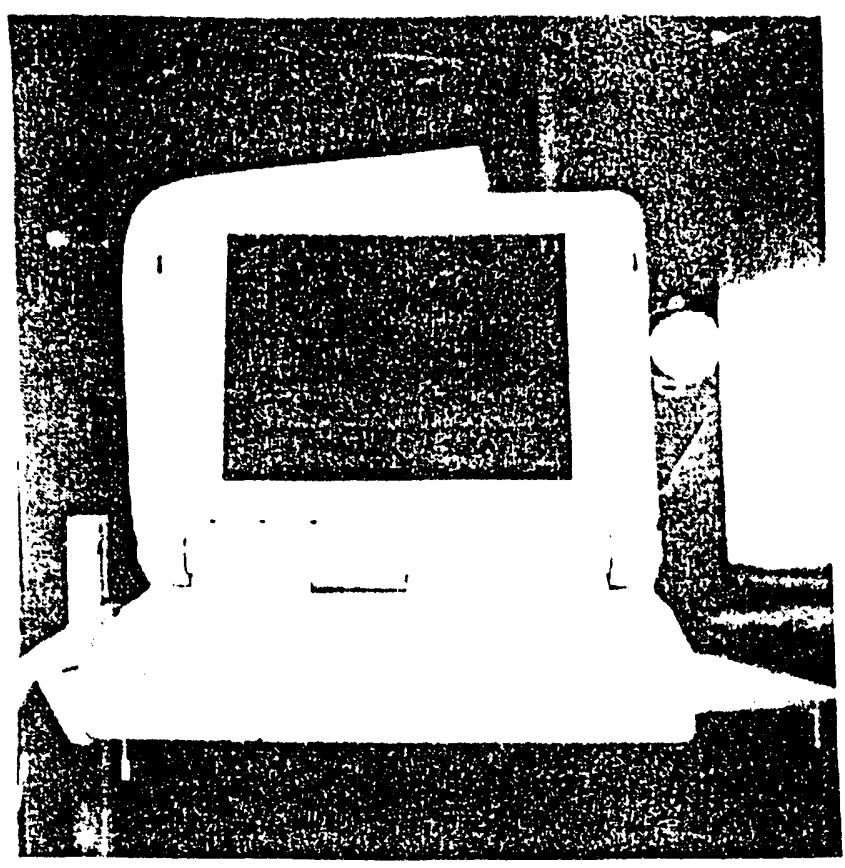

Figure 7. Location of the electronic clinonicter, (right of laptop), to measure the pitch of the combine indicating a change in topography.

Sortware- A software program entitled QI.ANI:?M, controls the FES system. This program wats originally written by Schumacher and lirochlich, to control the application of granular fertilizer via a laptop compuler (11). The software was modilied to eontrol and record field operations of a direct injection module in conjunction with a liquid chemical lield sprayer (12). Further modilications were made to apply the sofiware to the harvester system. Similar program format is maintained throughout each modilication, however programming lunclions vary depending on the application.

This program links the data logger to the laptop computer and records the ficld data pertinent to the objectives of the rescitrch. This data is yicld, grain moisture content, ground speed, distance, pitch, and roll. All dilla is sived onte a three and one-hall inch disketle. All data can he viewed later at the office and field maps can be produced. The variables can he monitored on the computer screen during harvest. The software divides the screen inte sections. The sections contain program commands, system operations, and field dat:i. Instructions that the user responds to include the field name, the date 
921651

of harvest, lane number, type of material being harvested, and some program control functions.

The software calls for and receives information from the data logger or interface control box. The voltages or pulses from these devices have had some signal conditioning and programming alterations before entering the software. This allows more of the laptop's time to be frec for other operating functions. The signals received by the software are then processed into a desirable output form. The current form allows data to be imported into spreadshects and mapping softwarc. After mapping, the information is used as a crop management tool.

\section{FIELD OPERATION}

An instantancous yicld mapping system was designed, built, and tested based upon the need for spatial variable farming practices (Figure 1). The components requirc some sctup and operation instructions. A description of the operating procedure is as follows:

1. A combine is fitted with a bracket to mount the ultrasonic sensor over the hopper of the combine. The hopper is calibrated hy corresponding a volume for a given depth of the grain (ligure 4).

2. The ultrasonic sensor is connected to the hopper bracket. The fifth whecl, clinometers, and grain moisture and temperature sensors are mounted on the combine. The laptop computer, RS-232 interface, Campbell Scientific $21 x$ Micrologger, control box, and ultrasonic driver box are place in the combine cab (Figure 3 ).

3. Nil sensors are connected to the control hox or data logger. The datal logger communicates with the laptop via the RS-232. The control box is connected to the combine's 12 vDC hattery. All power is regulated by the control hox hefore being supplied to the other components.

4. The operator drives the combine to the first lane of the field to be harvested. $\triangle$ program disk in Drive $\Lambda$ and a ficld disk is placed in Drive $B$ of the laptop. Disk $B$ will contain the data only for one field, therefore a new disk is necded for ench field.

5. The operator flips the power switch on, located on the control box, and flips the hold switch to the on position.

6. At the $\wedge$ promint the operator types the name of the program "QB Combine." The program loads and a program is also downloaded to the data logger. The system is now reidy for operalion.

7. The operator now answers questions describing the ficld's situation. This includes the longest lane, width of combine heid, name of the ficld, and type of operation.

8. The operator types in the lane to start combining, engages the harvesting system, switches the hold switch to the off position, and starts harvesting.

9. During harvesting the operator can observe the yield, grain moisture content, ground speed, and distance traveled down the lane on the computer sereen. All sensor output voltages are present on the screen during research for monitoring considerations. Yiclds and grain moisture readings are recorded every 12.2 meters so that the data can be used to produce yield maps. If combine or data acquisition system problems arise the hold switch can be llipped on. This "holds" all the current readings of the sensors and position in the field until the problem is solved. Then the switch is lipped off and harvesting can continue.

10. At the end of the lane the operator switches the change lane switch on. This saves the data from that lane automatically onto the disk in Drive B. The operator can now unload the combine hopper or sclect a new lane to harvest. Upon selecting a new lanc, the operator drives to the lanc, engages the harvesting system, and switches the change lane switch off while entering the new lanc. From this point on the operation of harvesting continues with the same procedure.

11. After the field is harvested all the data should already be stored onto the diskette in Drive B. At the office the operator can view the data (Figure 8), in raw form or a print out of a yicld map (Figure 9,10). The map can display the yield, grain moisture contents, date of harvest, and field name. This makes an excellent reference for next years crop production needs, and an instantancous tabulation of cach ficld's yiclds.

$\begin{array}{cccccccc}\text { Yield } & \text { Moist. } & \text { Temp. Slope1 Slope2 } & \text { Speed } & \text { Dist. } & \text { Lane } \\ \text { (mV) } & (m v) & (m V) & (m V) & (m V) & \text { (counts/s) } & (m) & \# \\ 2204 & 40 & 2743 & 2679 & 2697 & 4 & 45 & 7 \\ 2204 & 46 & 2742 & 2678 & 2706 & 3 & 80 & 7 \\ 2205 & 48 & 2742 & 2662 & 2681 & 4 & 120 & 7 \\ 2208 & 41 & 2742 & 2671 & 2686 & 4 & 163 & 7 \\ 2206 & 54 & 2742 & 2649 & 2673 & 5 & 211 & 7 \\ 2188 & 53 & 2741 & 2644 & 2689 & 4 & 241 & 7 \\ 2245 & 45 & 2741 & 2654 & 2700 & 4 & 288 & 7 \\ 2257 & 51 & 2742 & 2681 & 2707 & 4 & 331 & 7 \\ 2256 & 56 & 2741 & 2666 & 2722 & 4 & 366 & 7 \\ 2250 & 51 & 2741 & 2688 & 2725 & 4 & 408 & 7 \\ 2256 & 44 & 2742 & 2673 & 2720 & 4 & 442 & 7 \\ 2299 & 45 & 2742 & 2686 & 2707 & 4 & 484 & 7 \\ 2269 & 46 & 2741 & 2687 & 2709 & 4 & 526 & 7 \\ 2299 & 45 & 2742 & 2677 & 2720 & 4 & 560 & 7 \\ 2237 & 41 & 2742 & 2705 & 2708 & 5 & 603 & 7 \\ 2241 & 41 & 2741 & 2691 & 2702 & 4 & 645 & 7 \\ 2254 & 43 & 2741 & 2677 & 2708 & 4 & 691 & 7\end{array}$

Figure 8. Typical data recorded with the FGS harvester system. 


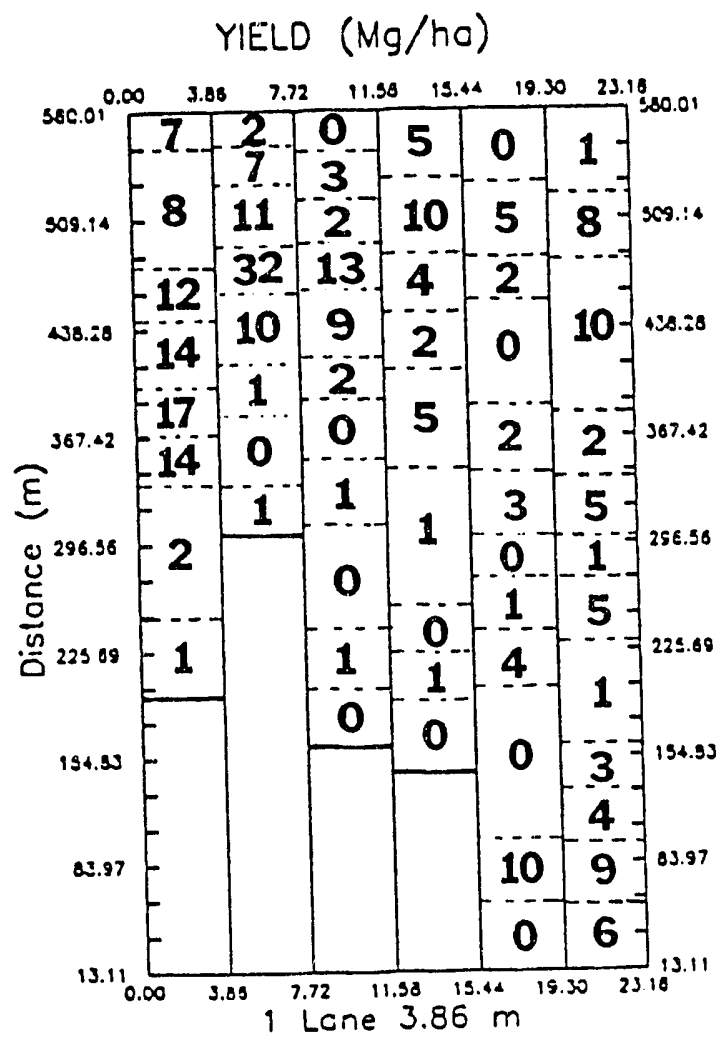

Figure 9. Field map displaying the yicld of a particular field. Arens of zero yield are due to downed corn.

\section{DISCUSSION AND SUMMARY}

The FGS system and QLANE ${ }^{\mathrm{TM}}$ software were adapted for the use with a combine to perform yield, grain moisture, and topography mapping. The system components, controlled with a laptop computer, have proven to be functional in laboratory and field evaluations. Accomplishments of the project are as follows:

1. Components needed to create the harvester system were selected and researched based on cost, operating principles, and adaption to harvesting systems.

2. An opcrational data collection harvester system, controlled with a laptop computer was designed and developed, and tested. A combine, laptop computer, and transducers were assembled to perform the system's objectives. The system was operated in the laboratory and in the ficld through common harvesting procedures. The system performed the desired objectives.

3. The programmable software, QLANE ${ }^{\mathrm{TM}}$, was adapted for recording data necessary for evaluating the system and mapping the grain yicld, grain moisture content, and topography.

4. Actual field maps depicting the grain yield, grain moisture content, and topography were generated with the collected data, (Figures 10,11, and 12). These maps can be used as crop management tools in conjunction with other site specific information.

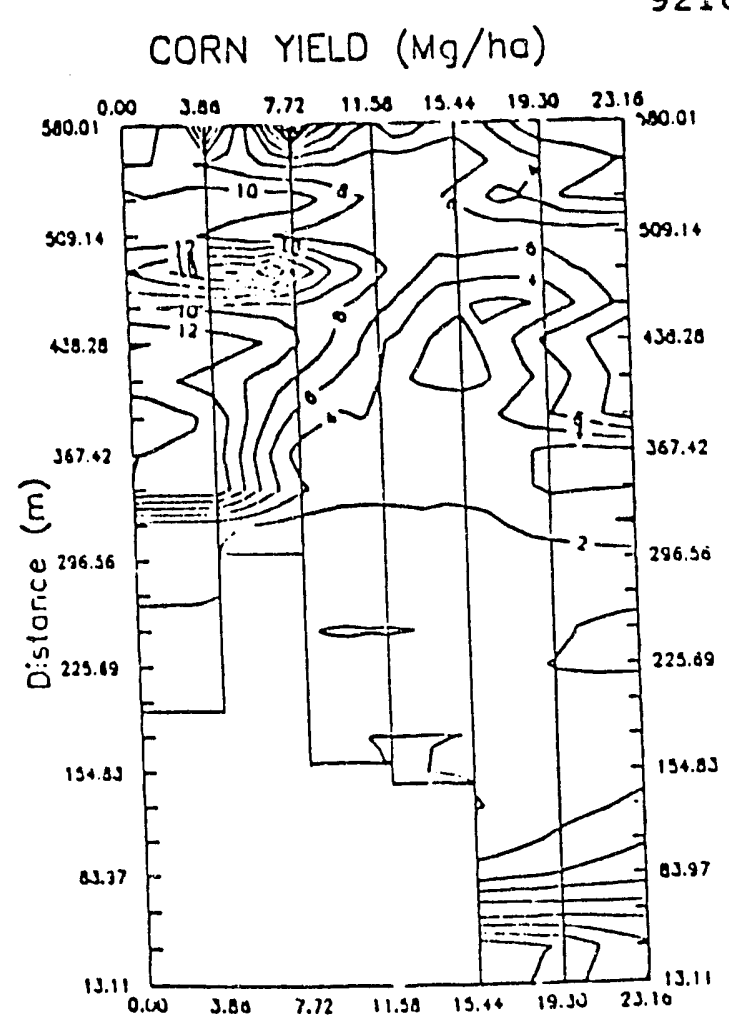

Figure 10. Topographic display of the yicld with interpolation methods emplesyed.

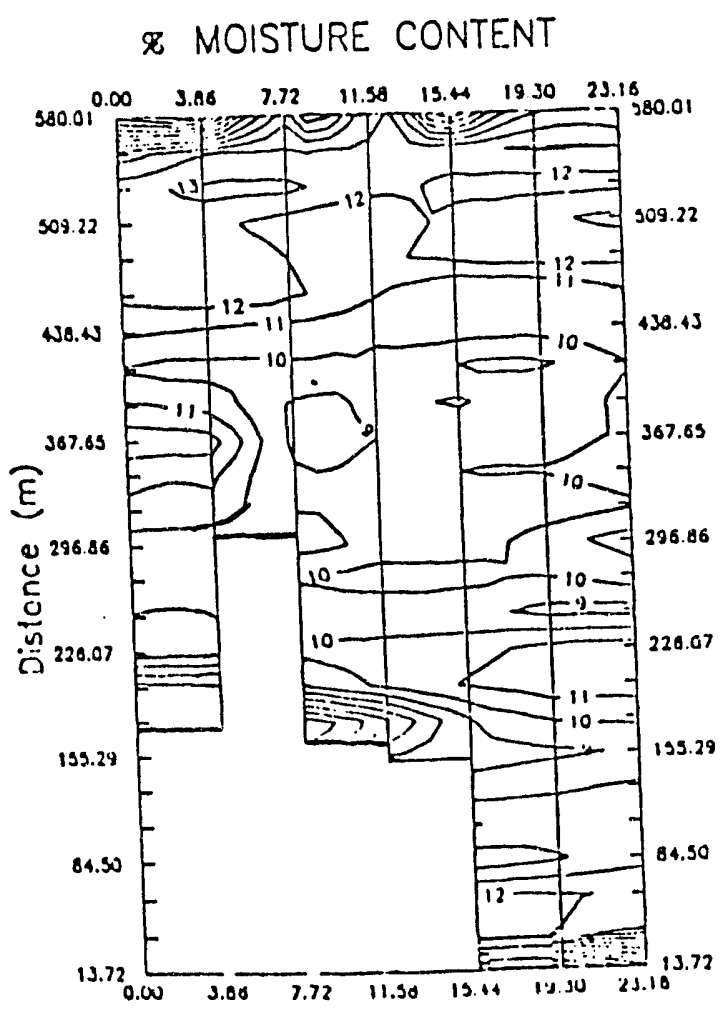

Figure 11. Map displaying the varying corn moisture contents throughout the ficld. 
collection area. Sitc specific yicld is considered a key component to farming spatially and further developments would be appreciated by many in this technological and agricultural spectrum. Continuing rescarch in technology, cconomics, and agronomics of spatial variable systems is a must to the development of a feasible and compatihle spatially variable management system.

\section{REFERENCES}

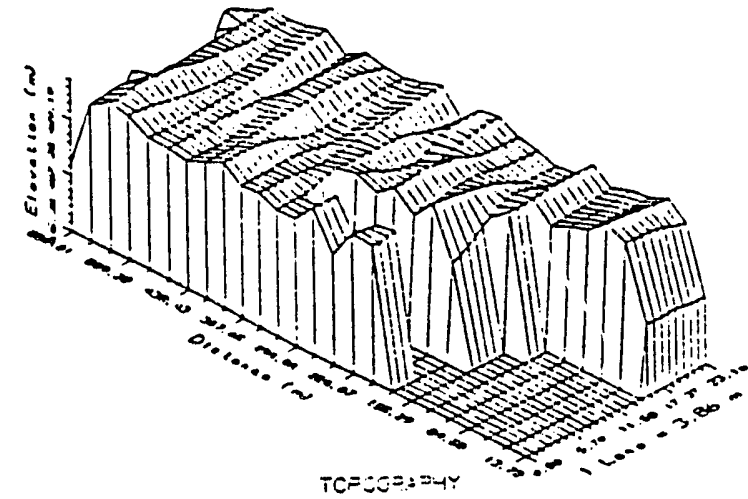

Figure 12. Map displaying the topography of the test ficld.

\section{CONCLUSIONS AND RECOMMENDATIONS}

Yicld mapping of grain was effectively performed with the measurement of position, lane width, grain moisture content, and depth of grain within the combine hopper.

Ultrasonic level sensing proved feasible as a method of determining the grain yield. Ilowever, improvements need to be made. These may consist of making several level readings in the combine hopper rather than at one location. An ideal system would create a topographic image of the surface of the grain in the combinc hopper, therefore insuring an exact known volume in the hopper. In general, using ultrasonics is a simple approach to a complex problem so that site specific farming can be employed.

The position sensing system was a simple and accurate method of determining location within a field. Currently this method is feasible for research and many farming operations. Ilowever, with technological advancements in other methods, such as (jPS, new and hetter methods might soon be more applicable.

The capacitance moisture sensor performed well and was reliahlc, but small problems still exist with sensing moisture of a moving medium and further research is necded.

The electronic elinemeters perforned satisfactory in producing data for the generation of useable topographic maps. More extensive rescarch might show more promising possibilities.

Further rescarch is necded in the site specific data
1. Pang, S.N. and G.C. Zoerb. 1990. A Grain Flow Sensor for Yicld Mapping. ASAE Paper No. 901633, ASAE, St. Joscph, MI 49085.

2. Bac, Y.II., S.C. Borgell, S.W. Scarcy, J.K. Schucller, B.A. Stout. 1987. Determination of Spatially Variable Yield Maps. ASAE Paper No. 871533, ASAE St. Joseph, MI 49085.

3. Peterson, C.L., J.C. Whitcraft, K.N. Hawley, and E.A. Dowding. 1989. Yield Mapping Winter Wheat For Improved Crop Management. ASAE Paper No. 897043, St. Joseph, MI 49085.

4. Wagner, L.E. and M.D. Schrock. 1987. Grain Flow Measurement with a Pivoted Auger. Transactions of the ASAE 30(6):1583-1596.

5. Vansichen, R. and J. DeBacrdemaeker. 1991. Continuous Wheat Yicld Measurement on a Combine. Procecdings of the Symposium, Automated Agriculture for the 21 st. Century. December, Chicago, Illinois. pp. 346-355. 6. Stafford, J.V., B. Ambler, and M.P. Smith. 1991. Sensing and Mapping Grain Yicld Variation. Proceedings of the Symposium, Automated Agriculture for the 21st. Century. December, Chicago, Illinois. pp. 356-365.

7. Burt, E.C., G.E. Monroe, J.II. Taylor, R.K. Wond. Building and Testing Traffic Lanes for Controlled-Traffic Farming. ASAE Paper No. 871056, ASAE, St. Joseph, MI 49085 .

8. Degan, Joseph. "Satellite Technology Comes Down To Earth." Farm Industry Ncws, November, 1991, pp.42-44.

9. Carlson, C.G., R. Dean, and G. Lemme. 1990. "Prescription planning: An appronch to nonpoint pollution problems." Journal of Soil and Water Conservation, Vol. 45, Number 2.

10. Falk, Brian. Telephone Intervicw. Consumer Services Department. Ford-New Holland, New IJulland PA. April, 1992.

11. Schumacher, J. 1990. Spatial Control of Crop Inputs Via Laptop and Typical Ficld Travel. M.S. Thesis, South Dakota State University, Agricultural Enginecring Department, Brookings, SD 57007.

12. Ollili, D.G., S.^. Schumacher, and D.P. Frochlich. 1990. Integrating Field Grid Sense System with Direct Injection Technology. ASAE Paper No. 901628, ASAE, St. Joscph, MI 49085. 

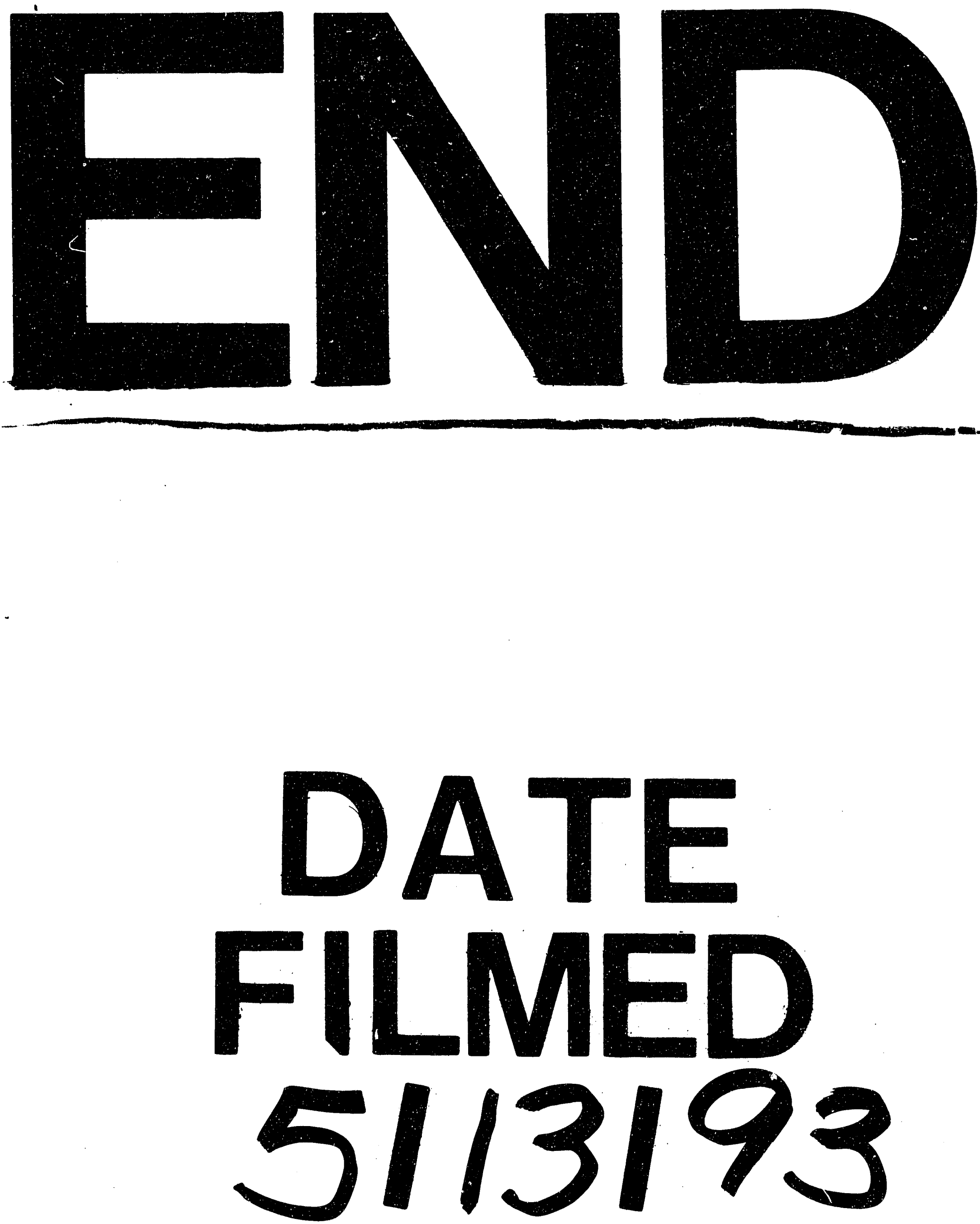


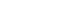

